\title{
Božja revolucionarna kvirnost
}

\section{Razgovarao: Mirza Halilčević}

Alen Kristić je teolog, publicist, prevoditelj i mirovni aktivist. Jedan je od pokretača regionalnog izdanja Međunarodnog teološkog časopisa "Concilium". Pored toga što je uredio niz publikacija posvećenih svjetskom etosu, čiji je regionalni promotor već više od jednog desetljeća, objavio je: „Religija i moć“ (Rabic, Sarajevo, 2009), „Graditeljice mira - društvenopolitički angažman dobitnica Nobelove nagrade za mir" (TPO Fondacija, Sarajevo, 2012), „Tiranija religijskog - Ogledi o religijskom bezboštvu“ (Rabic, Sarajevo 2014), „Prognani u zaborav - Fragmenti o pozitivnom potencijalu religioznog“ (Synopsis, Zagreb \& Sarajevo, 2015), "Gravitacije" (Shura Publikacije, Rijeka, 2017). U pripremi su njegova zbirka poezije "Agonije. Poetika tjelesno-političkog" i zbirka eseja "Religiološki ogledi. Rat - pamćenje - blasfemija".

Mirza Halilčević: Sjećam se da je u svojoj knjizi „Put kojim se rjeđe ide“, Skot Pek, pišući o svom psihoterapeutskom iskustvu i radu sa ljudima napisao kako ga Katolička crkva snabdijeva klijentima, pritom opisujući dogmatske dileme sa kojima se sreću vjernici, izazove i nedostatak intelektualno-religijskog koncepta. Da li bismo se mogli usuditi i reći da se i mi suočavamo sa sličnim kulturno-religijskim konfliktom, nikada do kraja integrisanim ili potpuno skrajnutim i ignorisanim?

Alen Kristić: Nepobitno je da su religije sakatile i sakate ljudska tijela i duše. Pregršt je primjera za to u iskustvu M. Scotta Pecka. No, njegovo nas iskustvo opominje da religije, uz umjetnost, raspolažu najraznovrsnijim i najsnažnijim resursima za čovjekovo ozdravljenje. Ključno je razumjeti zašto se religije, potencijalno bitne za ljudsko zrenje, prečesto izobličuju u polugu sputavanja ljudske slobode. $U$ tu bih svrhu podsjetio na rodno mjesto kršćanstva, koje u biti u većoj ili manjoj mjeri dijele sve religije. Riječ je o Tijelu stigmatiziranom trostrukom osudom - za rušenje društvenih normi pristojnosti, oskvrnuće religijskog pravovjerja i podrivanje političkog 
ustroja - i zato razapetom na smetlištu izvan gradskih zidina. Dakle, rodno mjesto kršćanstva, a stoga i mjesto njegovog trajnog začinjanja, bila bi društvena margina, na kojoj se okupljaju devijantni, neovisno o tome po kojoj su osnovi stekli etiketu devijantnosti od čuvara društvene ortodoksije - političkoj, ekonomskoj, nacionalnoj, religijskoj ili seksualnoj.

Premda je, reducirano na vlastitu karikaturu, stoljećima služilo za to, kršćanstvo nije pozvano na očuvanje društvenih konstrukta pristojnosti. Naprotiv, polazeći od iskustva devijantnih i solidarnog hoda s njima, kršćanstvo bi uvijek iznova trebalo dinamizirati i proširivati društvene konstrukte pristojnog zbog njima svojstvene kušnje fosiliziranja, pretendiranja na posjedovanje božanske legitimacije, zahtijevanja apsolutnog posluha i isključivanja svega što se ne uklapa.

Dakle, s obzirom na rodno mjesto, religije bi, umjesto statike moći, u svojim njedrima morale njegovati izvorni revolucionarni naboj. Da ne bi sakatile ljude, moraju neprestano hodočastiti na društvenu marginu kako bi, na osnovi iskustva devijantnih i konkretnih zahtjeva solidarnosti s njima, bespoštedno propitivale ne samo društvene nego i religijske normative. Štoviše, dostojanstvo religija položeno je u ruke devijantnih, a ne u ruke struktura naviknutih na lagodnu jalovost i diskriminacijsku samodostatnost centra.

Sve to znači da je krajnje vrijeme da religije solidarno stanu i uz bok seksualnih manjina - osoba koje se ne uklapaju u binarno-heteroseksualnu matricu - tim više, jer su upravo religije odigrale bitnu ulogu u ustrojavanju heteronormativnosti, prisvojivši monopolistički božansku legitimaciju heteroseksualnim normama seksualnog ponašanja i rodnog identiteta.

Na putu iskupljenja, religije bi u središte teološkog promišljanja morale integrirati i iskustva seksualno „devijantnih“ $i$, polazeći od njihovog usuda, ponovno kritički propitati kategorije teološkog mišljenja i s njima povezane religijske prakse, o čemu ne ovise samo, kako bi se naivno moglo pomisliti, zbivanja u spavaćoj sobi nego i društveni odnosi moći općenito.

Halilčević: No, religija je tu i kao kulturno naslijeđe i kao duhovni putokaz i kao resurs. Teško da se sve to može izignorirati, a pravo pitanje bi moglo biti kako i na koji način sintetizirati i integrisati religiju u moderne pokrete, kako je učiniti saveznikom u borbi protiv patrijarhalne hegemonije?

Kristić: Ključna prepreka za to je neprijateljska konstelacija sekularnog i religijskog odnosno teizma i ateizma u našem društvu. Daleko smo od savezništva sekularnog i religijskog u humanizaciji društva, čega je bitna sastavnica rušenje patrijarhalne hegemonije. Krivnju za to snose i religiozni i nereligiozni, jer u svom svjetonazoru nisu prerasli djetinje koncepte, koje obilježava isključivost.

Za većinu nereligioznih, uznika sekularnog fundamentalizma, religija je nasilna i nazadna, a religiozni zatucani fanatici. U njihovoj ideološkoj redukciji nema mjesta za složenost religijskog i doprinos religija humanizacijskim procesima. Za većinu religioznih, uznika religijskog fundamentalizma, nereligiozni ne mogu biti moralni, a sekularizacija je smrtni neprijatelj religije. U njihovoj ideološkoj redukciji nema mjesta za moralnu veličinu nereligioznih i blagotvorne efekte sekularizacije na autentičnost religija.

Osnažujući se uzajamno, te fundamentalističke vizure potiru činjenicu da je većina sekularnih koncepta sekularizirana verzija religijskih predodžbi, do čije je sekularizacije uglavnom dolazilo, jer su religiozni iznevjeravali plemenita religijska učenja. $U$ duhu potisnute srodnosti, danas bi sekularne koncepte i religijske predodžbe morali konstelirati tako da se uzajamno osnažuju i korigiraju, primjerice židovsko-kršćansku predodžbu „kćeri i sina Božjeg“ i islamsku „namjesnice i namjesnika Božjeg“ na jednoj strani i njihov sekularni korelat „nepovredivog ljudskog dostojanstva“ ili Dekalog i Deklaraciju o ljudskim pravima.

Dakle, uključivanje religijskih resursa u suvremene sekularne pokrete prije svega pretpostavlja oproštaj od religijskog i sekularnog fundamentalizma, a potom i oproštaj od mita o vlastitoj nedužnosti. Krivnju za uspon patrijarhalne hegemonije ne snose samo religije nego i sekularne tradicije, o čemu zorno može posvjedočiti već i rodno senzitivno čitanje Aristotela ili Platona.

Štoviše, premda su religije po sebi poprište sukoba sila sklonih i protivnih patrijarhalnoj hegemoniji, većini patrijarhalnih tumačenja religijskih izvora put je prokrčilo usvajanje patrijarhalizmu odanih stavova filozofa poput Aristotela i Platona.

$\mathrm{Na}$ koncu, bitna je spremnost trajnog učenja o drugom. Koliko nereligioznih poznaje feminističke teološke pokrete? Koliko je religioznih upoznato $s$ rodnim studijama ili postkolonijalnim teorijama?

Budući da patrijarhalna hegemonija opstaje vještim kombiniranjem sekularnih i religijskih oblika legitimacije, nije li krajnje vrijeme za 
savezništvo sekularnog i religijskog u njezinom rušenju? Zašto dopuštamo da religijsko bude učinkovit monopol radikalne desnice? Ako je Marx učio i crpio nadahnuće od Luthera, prvog kritičara ranog kapitalizma, zašto suvremeni ljevičari i liberali, sučeljeni s krizom političke imaginacije, zaziru od religijskog premda mu duguju izvorne postavke i poticaje?

Nije li krajnje vrijeme da se, svim svjetonazorskim razlikama unatoč, okupimo zajedno oko Marxovog kategoričkog imperativa, kao zajedničkog polazišta u humanističkoj preobrazbi društva: "Dokinuti sve odnose, u kojima je čovjek poniženo, potlačeno, zapušteno i prezreno biće..."

Halilčević: Činili se i Vama ponekad da se moderni pokreti, poput recimo LGBTIQA pokreta u regiji, pokušavaju kretati izolovano i distancirano od kulturnog naslijeđa, pa samim tim i od religijskog? Šta je moglo prethoditi tome? Je li tu ključna zapravo dogmatska, fabricirana interpretacija religije kao društvenog koncepta i ta nemogućnost uviđanja prostora za zajednički rad?

Kristić: Pored sekularnog fundamentalizma, niz je usko povezanih uzroka, koji zaziranje od religije u regiji čini razumljivim. Religije nisu očuvale kredibilitet ni sučelice ratnih ni sučelice tranzicijskih aveti. Smokvin list za to je savezništvo s nacionalističkim politikama, a njegova je cijena, kao i svakog religijskog savezništva s političkim, unatoč prividnim probitcima previsoka - nutarnja barbarizacija, koja se očituje u dominantnim religijskim narativima, iz kojih ne zaudara samo fundamentalizam nego sve češće i fašizam.

U slučaju LGBTIQA pokreta, to je zaziranje još razumljivije. U nastojanju da postanu tutori društvenog uz pomoć nacionalističkih politika, religije osnažuju homofobiju, stvarajući ponekad i ozračje linča. To mi je naročito potresno, jer takvo ozračje redovito sili religiozne LGBTIQA osobe na amputaciju njihovog religioznog identiteta, a stekao sam dojam - nadam se pogrešan - da nereligiozne LGBTIQA osobe u pravilu nisu senzibilizirane za tu dramu i ne pokazuju dostatnu solidarnost s religioznim LGBTIQA osobama, a upravo je to povlaštena prilika da u svom okruženju demonstriraju solidarno prihvaćanje različitog, za što se na koncu zalažu u društvu općenito.

No, koliko god razumio zaziranje od religije, posebice kod osoba, koje su religije traumatizirale, uvjeren sam da uspjeh suvremenih slobodarskih pokreta, pa iLGBTIQA pokreta, ovisi i o sposobnosti prevladavanja zaziranja od religije, i to u smjeru smjelog upuštanja u otkrivanje slobodarskih narativa u samim religijama i sklapanja savezništva s religioznim skupinama, koje, i same protjerane na marginu, razvijaju i baštine dotične narative.

Kao i u slučaju patrijarhalne hegemonije, protiv homofobije nemamo izgleda dok joj korištenjem religijskih resursa ne strgnemo krinku božanske legitimacije, a tim bi resursima trebale ovladati ne samo religiozne nego i nereligiozne LGBTIQA osobe. Bez tog ćemo se zaokreta u regiji teško izboriti protiv zakona, koji diskriminiraju seksualne manjine, a kamoli za zaokret u području kulture i mentaliteta, a tek to osigurava funkcioniranje zakona i zbiljsku slobodu. Dakako, to jednako vrijedi i kad je u pitanju borba za ženska prava, socijalnu pravdu ili očuvanje okoliša.

Na koncu, kad je riječ o LGBTIQA pokretu, važno je uzeti u obzir i krajnje specifičnu situaciju LGBTIQA osoba, koja se nerijetko, svjesno ili nesvjesno, zloupotrebljava. Nepobitno je da neke LGBTIQA osobe pripadaju ekonomskim i kulturnim elitama, uživajući izniman pristup moći i povlasticama, koje uz to idu, primjerice u SAD-u. No, većina je LGBTIQA osoba, naročito u društvenim krajolicima, kakvi prevladavaju u Latinskoj Americi, Africi, Bliskom istoku ili jugoistočnoj Europi, izložena istodobno višestrukim oblicima diskriminacije. Zastrašujući oblici nasilja, progona, zlostavljanja i izopćavanja od strane hegemonijske većine u tolikoj su mjeri rasprostranjeni i ukorijenjeni da sežu sve do obiteljskog konteksta. U svijetu više od 70 država kriminalizira osobe na temelju seksualne orijentacije ili rodnog identiteta, a u njih 7 homoseksualni odnosi su kažnjivi čak i smrću.

Nažalost, često se i sam pokušaj govora o zločinima iz mržnje spram LGBTIQA osoba, koje su u pravilu, ponovit ću to još jednom, nezaštićena meta ne samo seksualne nego i ekonomske, političke, rasne, nacionalne i religiozne diskriminacije, diskreditira upiranjem prsta na LGBTIQA osobe, koje su postale dio ekonomske i kulturne elite - ne samo na njihov način života općenito nego i na način manifestiranja njihove seksualne orijentacije u javnoj sferi - premda su one u cjelokupnoj LGBTIQA populaciji posvuda, a naročito u društvenim krajolicima sličnim našem, manjina.

Halilčević: Alene, koji bi to bili konkretni koraci i smjernice za djelovanje u pravcu kretanja otkrivanja novih pokvirenih religijskih vizura, odakle bismo mogli početi obzirom da je na ovom polju urađeno jako malo?

Kristić: Budući da kod nas tek treba poduzeti prve ozbiljne korake, osjećam potrebu podsjetiti na to što znači kvir u kontekstu kvir teorije 
kako bih potom pojasnio što bi to bila kvir teologija, polazeći od kršćanske tradicije.

Dakle, u kontekstu kvir teorije, kvir se tiče teorijskog zanimanja za raskrinkavanje konstruiranosti tobože prirodnih kategorija rodnog identiteta (muško - žensko) i na taj način normi, koje se odnose na seksualno ponašanje (heteroseksualnost). Riječ je o propitivanju zapadnjačkog načina mišljenja u binarnostima, koje obilježava nasilna logika ili - ili, počevši od izvorne binarnosti muškarac ili žena, i hijerarhija, na kojima to mišljenje počiva, producirajući nepromjenjive i nesavladive granice (čisto - nečisto, ljudsko - božansko, tijelo - duh, bijelo - crno, heteroseksualno - homoseksualno...). To je bitno, jer se fiksirane kategorije koriste za konstrukciju drugačijosti i legitimizaciju isključivanja. Iz tog je razloga krajnji cilj kvir teorije uspostava veće pravednosti.

Prihvaćajući kritičko značenje pojma kvir, kvir teologija je usmjerena kritici binarno-hijerarhijskih kategorija teološkog mišljenja i privilegiranja povlaštene vrste iskustva $\mathrm{u}$ religijskoj tradiciji (bjelačke, muške, heteroseksualne...). Njezin je krajnji cilj raskrivanje načina na koje je teologija osiguravala božansku legitimaciju različitim strukturama dominacije kroz povijest do danas. U raskrinkavanju prikrivene ili zanijekane sukrivnje teologije za političke, ekonomske i seksualne oblike izrabljivanja od presudnog su joj značenja iskustva marginaliziranih skupina - žena, homoseksualaca, kvir osoba... - koje su često izložene različitim oblicima izrabljivanja istodobno.

Pored toga, za kvir teologiju je važno rekonstruirati na koji je način teologija pridonijela razvoju heteroseksualne normativnosti i s kojim je to devijacijama izvorne religiozne poruke povezano, počevši od isključivanja seksualnosti i tijela iz teologije do posvemašnjeg sunovrata teologije u totalitarizam. Bilo da teologiziraju polazeći od iskustva kvir osoba ili kao kvir osobe, kvir teolozi u teološka promišljanja unose "perverzna" ili "devijantna" iskustva osoba s margine. Na taj način teologiju otimaju lagodnoj usidrenosti u kulturno dominantno i podsjećaju na to da je izvorno područje teologiziranja susret $s$ onima na društvenoj margini, bilo da je riječ o gubavcu, cariniku, migrantu, prostitutki, lezbijki ili transvestitu, jer glas marginaliziranih, ukoliko mu se izložimo, proročkom oštricom raskida zastore ravnodušnosti oko nas i otvara nam oči za područja od kojih smo, zakazujući u solidarnosti i pravednosti, čistunsko pobožnjački okretali glavu, a na kojima nas božanski Duh s marginaliziranima očekuje da mu se pridružimo u osmišljavanju dobrog života za sve.

$\mathrm{Na}$ koncu, kvir teologija vraća svijest teologiji o tome da je njezin temeljni preduvjet i poziv biti kvir - biti nastrana, na krivom mjestu i strana u suvremenom materijalističkom, komodificiranom i empirističkom neoliberalnom svijetu, kako to zamjećuje Gerard Loughlin. Štoviše, i pozicija teologije je krajnje kvir, jer pokušava razumjeti ono što je $s$ onu stranu spoznaje - Boga.

U konačnici, temeljna su kršćanska učenja, ništa manje od kršćanskog simboličkog imaginarija, izrazito oprečna binarnim kategorijama mišljenja, pa tako, primjerice, utjelovljenje satire granicu ljudskog i božanskog, uskrsnuće dokida razlikovanje života i smrti, Trojstvo govori o tri osobe u jednom biću, čija rodna obilježja nisu fiksirana, sam je Isus Krist - može li se biti korjenitije protivan prisili binarnog - Bogočovjek...

Zapravo, poziv kvir teologije i jest prizvati nam sve to iznova u svijest kviringom kršćanskih izvora $\mathrm{i}$ tradicije, a to i jest u konačnici ključni preduvjet oproštaja teologije od heteroseksualne logike ili - ili i njoj svojstvene opsesije kategorizacijom i isključivim granicama u prostoru kršćanske misli i prakse.

$\mathrm{Na}$ dugoj stazi dosezanja kontekstualne kvir teologije kršćanskog i islamskog formata, prvi bi korak bio omogućiti regionalnu recepciju ključnih djela kvir teologije na globalnoj razini sustavnim i kvalitetnim prijevodima, što je po meni silan i za budućnost presudan izazov i za regionalne LGBTIQA pokrete, a to bi potom omogućilo pokretanje utemeljenog i otvorenog dijaloga o kvir temama is religioznog stajališta is osvrtom na regionalne posebnosti.

Pogubno je budemo li i dalje dopuštali da to bude tabu i ne stvorimo li slobodne prostore govora, u kojima će stasati regionalni kvir teolozi. Bez tog će se, ponavljam svoje duboko uvjerenje, u konačnici jalovim pokazati i sekularna nastojanja razgradnje patrijarhalne hegemonije i homofobije.

Halilčević: Sjećam se, Drago Bojić je jednom prilikom rekao i čini mi se negdje zapisao kako Boga treba zaštititi, stati u njegovu odbranu, jer se njegovo ime sve više zloupotrebljava. Je li s tim u vezi došlo vrijeme i da oni, kojima se možda ponajviše osporava korištenje Božjeg imena, stanu u odbranu Boga, a kad kažem oni - pritom uglavnom mislim na LGBTI populaciju?

HUMANISTIKA - Vol. 2. Broj 4 - Oktobar 2018. 
Kristić: Prepustiti neko područje isključivo ekspertima u biti neizbježno znači prepustiti ga pogubnim izobličenjima. Premda nisam ekonomist, silno me se tiče, koja je ekonomska paradigma na snazi u mom društvu. Premda nisam političar, silno me se tiče, koja je politička kultura dominantna u mom društvu. Slično tomu, čak i ako nisam religiozan ili teolog, na moj život u svima njegovim aspektima utječe i to što vjerovanje u Boga znači u mom društvu, a, nerijetko, što je taj utjecaj suptilniji, to je dalekosežniji. U pravu je moj prijatelj, koji je jednom prigodom istaknuo da se čak i onda kad ne znamo tko je Bog ili u njega uopće ne vjerujemo moramo, ulažući sav svoj trud i sve svoje kritičke potencijale, proročki uplesti u otkrivanje toga tko Bog zasigurno nije i što vjera nikako ne bi smjela značiti u društvu.

Dakle, ni Bog ni promišljanje o Bogu nije ničiji monopol - ni religioznih, ni teologa ni vjerskih poglavara - jer u protivnom više ne bi bio Bog nego plemenski, strukovni ili religijski totem. Nije slučajno Isus jednoć upitao učenike što ljudi kažu tko sam ja, sugerirajući da pitanje o Bogu mora ostati otvoreno, jer je svaki odgovor na to pitanje provizoran, a doslovce ubilački od trena, u kojem se, potirući vlastitu kontigentnost, proglasi apsolutnom spoznajom.

Štoviše, kroz kršćanske se svete spise kao crvena nit provlači paradoks da su donositelji revolucionarnih uvida o Bogu i nositelji autentične vjere redovito bili upravo proskribirani i otpisani od okorjelog pravovjernog centra - stranci, gubavci, carinici, pogani, prostitutke, proroci... - rekli bismo danas s punim pravom kvir osobe. Ponavlja se taj paradoks i kroz povijest kršćanske tradicije. Ostavljajući za sobom razdoblja stagnacije i sterilnosti, teologija je doživljavala revolucionarne uspone jedino onda kad se bez straha izlagala stranom - iznova bismo mogli reći kvir zbiljama neovisno o tome jesu li to bile nove filozofske koncepcije, nove znanstvene spoznaje ili novi umjetnički pravci.

U tom je smislu krajnje vrijeme da se i u našem društvu ne samo religiozne nego i nereligiozne LGBTQA osobe smjelo uključe u hrvanje oko pitanja što vjerovanje u Boga ni u kojem slučaju ne bi smjelo biti i kakav bi to Bog doista mogao biti.

No, kad je riječ o religioznim LGBTQA osobama to je dodatno važno, jer nam upravo njihova religioznost i njihova teološka promišljanja mogu na presudan način pomoći da s Božjeg lica strgnemo heteroseksualne zastore, koje je isključivo heteroseksualna teologija tkala stoljećima, izobličivši mnoge crte na Božjem licu. Naravno, „izaći iz ormara“ i biti „autovana“ kvir osoba, a uz to i ,autovan“ kvir teolog ili teologinja, uključuje iznimnu odvažnost u našem kontekstu, na koju možda može potaknuti spoznaja da je zapravo i sama Božja objava čin kvir autovanja, kako to s pravom sugerira azijsko-američki kvir teolog Patrick Cheng.

Satirući apsolutnu granicu božanskog i ljudskog, i sam se Bog „autova“" pred ljudima u tolikoj mjeri - tako se vjeruje u horizontu kršćanske tradicije - da je postao ljudsko biće, i to marginalizirano ljudsko biće, ističući da su upravo marginalizirani povlašteno mjesto Božje nazočnosti. Iz tog je razloga i sama Božja ljubav radikalno kvir, jer dokida granice i stvara nove mogućnosti. Religiozna iskustva kvir osoba mogu nam pomoći da povratimo svijest o tome da je istinska narav božanske ljubavi kvir, doslovce protivna društveno propisanim granicama i normama, pa u tom smislu i radikalno prestupnička.

Na koncu bih istakao i svoje duboko uvjerenje da bi nam religiozna iskustva i teološka promišljanja LGBTQA osoba u našem kontekstu pomogla u dekonstrukciji dominantne teološke paradigme, koja je smrtno zaražena virusom nacionalizma i militarizma, a poznato je u kojoj su mjeri upravo nacionalizam i militarizam homofobni.

Halilčević: Termin kvir je svojevremeno označavao vrlo pogrdan naziv u LGBTIQA krugovima. Koristio se s ciljem vrijeđanja i diskreditiranja. Poslije je reclaimingom taj pojam prihvaćen, obgrljen, te mu je upisana nova simbolička, plemenita vrijednost. Vjeruješ li da bismo možda nešto slično mogli uraditi i sa religijom i njenim tumačenjima? Vjeruješ li da bismo u religiju mogli učitati nove vrijednosti univerzalne ljubavi ili jednostavno obnoviti neke zaboravljene i skrajnute?

Kristić: Zanimljivo je da je upravo križ, kao temelini kršćanski simbol, doživio sličnu preobrazbu kao i pojam kvir - od sprave za likvidaciju društveno i religijski prokletih do znaka Božje sveobuhvatne ljubavi i spasenja - što iznova aludira na to da je izvorna narav religijskog kvir.

Naravno da je moguće preoblikovati religijska učenja i tumačenja $u$ smjeru zornijeg svjedočenja univerzalne ili, kako bi to rekao P. Cheng, radikalne ljubavi. Štoviše, tragove borbe za takva preoblikovanja nalazimo i u samim svetim spisima - primjerice, Filip, protivno propisima Tore (Pnz 23,2), krsti etiopskog eunuha (Dj 8,26-40), nadahnut po svoj prilici krsnim obrascem, kojeg nam je posredovao Pavao (Gal 3,28$)$-a naš poziv nije poput

HUMANISTIKA - Vol. 2. Broj 4 - Oktobar 2018. 
statista zadivljeno stajati nad tim revolucionarnim pomacima u shvaćanju Božje objave nego odvažiti se na to da postanemo dovitljivim nastavljačima tog dinamizma u svom kontekstu.

Vjernost religijskim izvorima i tradiciji ne očituje se u njihovom pasivnom čuvanju pod staklenim zvonom nego - shvatimo li tradiciju kao lanac - u smjelom i kreativnom kovanju nove karike $\mathrm{u}$ tom lancu, a to često zahtijeva kritiku tradicijskih pretpostavki i njihovog okretanja naglavce, ono do čega je, putem kviringa, naročito stalo kvir teologiji. A predmetom kviringa u području religijskog može i treba postati baš sve, u slučaju kršćanstva, primjerice, Bog i Trojstvo, Isusa i Marija, Crkva i sakramenti.

Da je to moguće i neke od načina kako se to čini krajnje uspješno i blagotvorno, zorno pokazuje monumentalni zbornik „Kvir teologija. Ponovno promišljanje zapadnjačkog tijela“ [„Queer Theology. Rethinking the Western Body“], koji je uredio već spomenuti Gerard Loughlin, a izdala izdavačka kuća Blackwell još 2007. Bilo bi čudesno dobiti tu, koliko obimnu toliko i uspješnu, laboratoriju teološkog kviringa kršćanskog tradicijskog blaga na našem jeziku. No, dopustite mi pojasniti dodatno zašto baš kviring kao teološka metoda, počevši od kviringa Boga.

Baštinjene predodžbe o Bogu nisu nevine. Naprotiv, autoritarna i isključiva dominacija bjelačkog, muškog i heteroseksualnog u procesu tradicijskog razvoja predodžbe Boga izazvala je njezina brojna izobličenja, uključujući i ukotvljavanje nasilja u samu predodžbu Boga, koje potire različitost i mnogostrukost. Ne treba zaboraviti da dominantna predodžba o Bogu služi ne samo kao matrica za oblikovanje ljudskog subjekta nego i za discipliniranje društva, posebice isključivanje onih, koji se ne uklapaju u predodžbu Boga, za koju „mi“ vjerujemo da je jedina ispravna. Ponavljam, kroz kršćansku povijest, baš kao i islamsku, to „mi“ bili su gotovo bez iznimke bijelci, muškarci i heteroseksualci.

Dakle, kviring Boga, naročito predodžbi Boga, poput patrijarhalne glave njegove zaručnice Crkve ili nepromjenjivog, homogenog, svemoćnog i suverenog entiteta nesposobnog za patnju, potreban nam je da bismo Boga konačno oslobodili steznika stoljećima dominantne bjelačke, muške i heteroseksualne teologije. Naravno, heteroseksualno nije po sebi problem, ni općenito ni u teologiji, ali jest njegova društvena ili teološka apsolutizacija i na taj način izobličavanje u prikrivenu rodnu ideologiju u srcu same teologije ili samog društva. Naprosto, da bismo se približili istinitijoj predodžbi o Bogu, konačno moramo čuti i glasove onih stoljećima ušutkavanih!

Iz tog nam je razloga potreban i kviring Trojstva. Višestoljetna dominacija strejt teologije izobličila je predodžbu o unutarnjim odnosima u Trojstvu - Oca, Sina i Duha - i to ne samo njihovim fosiliziranjem i umetanjem u binarnu matricu muškog i ženskog subjekta, zajedno s njihovim cementiranim pozicijama sukladno njihovoj „prirodi“ $i$ heteroseksualnosti. Pored toga, strejt teologija je u Trojstvo umetnula hijerarhije (prvenstvo Oca), što je oprečno izvornoj kršćanskoj postavci o Trojstvu, koje čine tri apsolutno jednake osobe. A onda su tako izobličeni odnosi u Trojstvu postali društvenom normom, pružajući božansku legitimaciju dominantnosti i prvenstvu muškog na jednoj strani i pokornosti i pasivnosti ženskog na drugoj strani (penetracijski odnos Oca i primateljskog Sina ili aktivnost trojedinog Boga i pasivnost zaručnice Crkve). Dakako, sve to i uz cementiranje rodnih uloga unutar Trojstva, dok nas kviring Trojstva, s druge strane, podsjeća na to da je Trojstvo "ménage-à-trois“, u kojem je „svaka osoba strastveno povezana s drugom, a i odnos Boga i ljudskih bića promiskuitetan i poliamoran, jer božansko biće strastveno želi sve ljude, muškarce i žene“, premda se mnogi od njih ne uklapaju u društvene norme, kako to ističe Stefanie Knauss.

Slično se zbilo i s Isusom Kristom, koji se, promatran isključivo kroz heteroseksualnu optiku, izobličio u „Mesiju sistema“, „Krista jasnih ograničenja i granica“, „potentnog muškog ljubavnika svoje pobožne zaručnice Crkve“, legitimirajući na taj način hijerarhijski odnos subjekata, kako to opaža sjajna kvir teologinja M. Althaus-Reid. Jednostranost heteroseksualne optike gurnula je u zaborav „Isusovu neuhvatljivu fluidnost“, činjenicu da je Isus bio „izuzetan prekoračitelj granica, neovisno o tome je li riječ o božanskim, društvenim, seksualnim ili rodnim granicama", kako to dojmljivo formulira P. Cheng. Zato je M. AlthausReid, koristeći kviring metodu, razvila biseksualnu kristologiju. Riječ je o biseksualnosti utjelovljenoj $\mathrm{u}$ Isusu ne u smislu seksualnih čina nego $\mathrm{u}$ smislu načina mišljenja i egzistiranja, koji je utemeljen na logici i - i, a ne na heteroseksualnoj logici ili - ili. Kao i za samog Isusa, za biseksualnu kristologiju polazište nisu apstraktne kategorije ili načela nego solidarno ponašanje, za koje poticaj pronalazi u marginaliziranim, u prvom redu kod onih, koji ne udovoljavaju heteroseksualnoj logici. Iz tog razloga 
biseksualnoj kristologiji i polazi za rukom kritički propitivati postojeće hijerarhije, stabilnosti i zatvorenosti u prilog veće otvorenosti, kreativnosti i diskontinuiteta.

Za kršćanstvo je, naročito katoličku tradiciju, iznimno važan kviring Marije. Budući da su upravo mnoga teološka promišljanja o Mariji i marijanske pobožnosti izuzetno pervertirano i vrlo snažno sredstvo discipliniranja žena i njihovih tijela, kviring Marije je preduvjet ponovnog dosezanja njezinih slobodarskih potencijala, i to ne samo za žene nego za društvo općenito. Simbolički kazano, često se pod Marijinim skutima u Crkvi još uvijek krije falus muške represije.

Nadalje, bitan je i kviring predodžbe Crkve kako bi Crkva konačno postala zajednica drugačijih, u kojoj se razlike cijene, jer će jedino tako LGBTIQA osobe u Crkvi pronaći svoje mjesto bez nasilnog podvrgavanja heteronormativnom idealu. A to je preduvjet da u Crkvi konačno nesmetano procvjetaju darovi božanskog Duha, koji su položeni u LGBTIQA osobe - i na dobro Crkve i na dobro društva općenito.

Na koncu, nužno je istaknuti da, uz razvoj kviringa kao teološke metode, u našem kontekstu treba pod hitno stati u kraj i zloupotrebi biblijskih i paralelnih kuranskih mjesta kao dokaza božanske osude LGBTIQA osoba, a u duhu vulgarno-fundamentalističkog tumačenja svetih spisa. Suvremene metode tumačenja svetih spisa, i u slučaju kršćanstva i u slučaju islama, koje, uz ostalo, u obzir uzimaju cjelinu svetopisamske poruke i povijesni kontekst, više su nego jasno dokazale da biblijska i kuranska mjesta, za kojima se u tu svrhu tradicionalno poseže, razrješuju i govore o posve drugim životnim izazovima. Te bi spoznaje morale doprijeti i do svijesti regionalnih vjerskih poglavara, teologa i vjernika. I na regionalnim LGBTIQA pokretima je da nešto konkretno i sustavno učine u tom pogledu.

Halilčević: Primjer reclaiminga vjere se zapravo već dogodio u nekim mjestima u svijetu, a vrlo značajan instrument u tom procesu je upravo bila i umjetnost. Mnogi religijski motivi, poput lika Isusa, su vrlo često bivali izvorom nepresušne inspiracije za mnoge LGBTIQA umjetnike i događalo se naravno svašta, mišljenja i ljudi su se dijelili, ali je umjetnost nastavila svoj proces stvaranja. Šta bismo mi u tom pravu mogli uraditi, ili na šta bismo se mogli podsjetiti?

Kristić: Pomaci se zbivaju u svijetu. Mnoge su kršćanske crkve LGBTIQA osobe prihvatile kao Božji dar i punopravne članove. Silno me raduje da je papa Franjo, potičući rasprave u duhu otvorenosti, i u Katoličkoj crkvi izazvao pravu revoluciju glede katoličkog pogleda na obitelj i LGBTIQA osobe, a ta revolucija još uvijek traje premda do nas na jugoistoku Europe malo od nje dopire.

U Njemačkoj o tome, primjerice, svjedoči izvrstan zbornik "Tko sam ja da mu sudim? Homoseksualnost i Katolička crkva" ["Wer bin ich, ihn zu verurteilen? Homosexualität und katholische Kirche], koji je uredio Stephan Goertz, a objavio ugledni katolički izdavač Herder 2015. Noseći, nipošto slučajno, kao naslov odgovor pape Franje na pitanje što misli o homoseksualcu koji traži Boga, taj zbornik zorno pokazuje u kojoj je mjeri suvremena katolička teologija iz perspektive izvorne Isusove poruke u svim svojim disciplinama razotkrila neodrživost trenutnih stavova Katoličke crkve prema LGBTIQA osobama i koliko je hitno revidiranje tih stavova kako bi Katolička crkva bila autentična s obzirom na Isusovu izvornu poruku i kako više ne bi bila izvor patnje za LGBTIQA osobe. Pred nama je borba da ti uvidi postanu svojina crkvenog učiteljstva i vjerničkog puka. A u tome veliku ulogu može odigrati upravo umjetnost.

Zapravo, umjetnost je, bilo književnost, poezija, slikarstvo ili film, i u prošlosti nerijetko krčila put teologiji na stazi ponovnog raskrivanja izvornog Isusovog učenja i prakse. I danas se kvir teologija u velikoj mjeri nadahnjuje umjetnošću.

Pred religijama je izazov, posebice u našoj regiji, naučiti se na provokativna umjetnička djela ne reagirati jeftinim etiketiranjem kako su blasfemična, prekidajući komunikaciju i s njima i s njihovim autorima. Naprotiv, bilo bi nužno da se religije izlože onom uznemirujućem i bolnom u njima ne bi li na taj način raskrile mjesta u društvu, od kojih okreću glavu, a koja bi zapravo trebale pohoditi, i to ne samo da bi solidarnošću s ljudima, koji se na tim prezrenim mjestima bore za ljudsko dostojanstvo, na uvjerljiv način posvjedočile Božju ljubav nego da bi - prije toga, a u svrhu vlastitog institucionalnog obraćenja - čule navještaj Boga od samih patnika - kroz kršćansku povijest, sve do danas, prečesto prezrenih evangelizatora.

Drugim riječima, religije se nalaze pred izazovom ponovnog otkrivanja religiozne produktivnosti blasfemijskog. Duboko sam uvjeren $\mathrm{u}$ to da Bog danas, baš kao nekoć preko starozavjetnih proroka, vrlo neugodnih za onodobni religijsko-politički establišment, često progovara upravo 
kroz umjetnike, čija se djela iz religijskih krugova olako proglašavaju blasfemičnim.

Sila je umjetničkih djela u našoj regiji - valjda je umjetnost još jedino što u našim društvima funkcionira - kojim bi se religije trebale izložiti ne bi li uočile vlastita zakazanja u društvu i otkrile ljudskije načine djelovanja. Nedavno me silno razveselila spoznaja da kod nas postoje i takva izrazito kvir djela premda od društva u cjelini nisu ni prepoznata, a kamoli priznata. Mislim na krajnje provokativnu, izuzetno smjelu i teološki vrlo produktivnu fotografiju "Blago(meni)vijesti" mlade sarajevske umjetnice Dženane Šaldić, koja predstavlja sjajan kviring slike "Blagovijest" Dantea Gabrijela Rossettija.

Halilčević: Ja sam imao priliku i da premijerno virnem u tvoju novu zbirku kvir-teološke poezije koju pripremaš i pored toga što sam oduševljen britkošću tvog jezika i sveobuhvatnošću tvojih simbola, posebno me se dojmila vrlo široka angažiranost. Ti tamo i pored brojnih kvir elemenata kojima se baviš, govoriš i o pravima radnika, o ugnjetavanju žena, o toksičnom maskulinitetu, o crkvenoj hegemoniji, čini mi se kao da nas tamo sve pozivaš i podsjećaš na sveopće antifašističke vrijednosti, važnost solidarnosti i ujedinjenja, jesam li upravu?

Riječ je o zbirci "Agonije. Teopoetika tjelesno-političkog". Poetski propitujući skandalozno izobličenje Isusova učenja i prakse u životu kršćana, zbirka predstavlja i svojevrsni poetski putopis mog ljudskog, vjerničkog i teološkog hoda. A njegova os od samog početka do danas jesu margina i marginalizirani, kao mjesto povlaštene Božje nazočnosti. To je izvorište njezine obuhvatnosti i u smislu simbola i u smislu tema, jer je gotovo nemoguće nabrojati sve vrste marginaliziranja i marginaliziranih u suvremenom svijetu.

No, jedna od njezinih bitnih poruka je - to je i jedno od središnjih otkrića i poruka kvir teologije - da su na prvi pogled različite borbe - borba za ljudska prava, borba za ženska prava, borba za očuvanje okoliša, borba protiv obiteljskog nasilja, borba za prava LGBTIQA osoba, borba protiv patrijarhalne hegemonije, borba protiv neoliberalnog kapitalizma... - jedna te ista borba. Ukoliko to ne shvatimo i ne ujedinimo se, učeći kombinirati u toj borbi i sekularne i religiozne resurse, unaprijed ćemo sami sebe osuditi na poraz! 